\title{
Lithium peroxide crystal clusters as a natural growth feature of discharge products in $\mathrm{Li}-\mathrm{O}_{2}$ cells
}

\author{
Tatiana K. Zakharchenko ${ }^{\ddagger 1}$, Anna Y. Kozmenkova ${ }^{\ddagger 1}$, Daniil M. Itkis ${ }^{* 1,2}$ \\ and Eugene A. Goodilin 1,2
}

Open Access

\author{
Letter

\section{Address:} \\ ${ }^{1}$ Department of Materials Science, Moscow State University, \\ Leninskie gory, Moscow 119991, Russia and ${ }^{2}$ Department of \\ Chemistry, Moscow State University, Leninskie gory, Moscow \\ 119991, Russia \\ Email: \\ Daniil M. Itkis* - daniil.itkis@gmail.com \\ * Corresponding author $\ddagger$ Equal contributors \\ Keywords: \\ lithium-air batteries; lithium peroxide; oxygen reduction reaction
}

\author{
Beilstein J. Nanotechnol. 2013, 4, 758-762. \\ doi:10.3762/bjnano.4.86 \\ Received: 30 June 2013 \\ Accepted: 16 October 2013 \\ Published: 15 November 2013 \\ This article is part of the Thematic Series "Energy-related nanomaterials". \\ Guest Editors: P. Ziemann and A. R. Khokhlov \\ (C) 2013 Zakharchenko et al; licensee Beilstein-Institut. \\ License and terms: see end of document.
}

\begin{abstract}
The often observed and still unexplained phenomenon of the growth of lithium peroxide crystal clusters during the discharge of $\mathrm{Li}-\mathrm{O}_{2}$ cells is likely to happen because of self-assembling $\mathrm{Li}_{2} \mathrm{O}_{2}$ platelets that nucleate homogeneously right after the intermediate formation of superoxide ions by a single-electron oxygen reduction reaction (ORR). This feature limits the rechargeability of $\mathrm{Li}-\mathrm{O}_{2}$ cells, but at the same time it can be beneficial for both capacity improvement and gain in recharge rate if a proper liquid phase mediator can be found.
\end{abstract}

\section{Findings}

The idea to utilize oxygen as an oxidizer in rechargeable batteries has been kept in mind for a long time because of the easy availability of $\mathrm{O}_{2}$ in ambient air. Alkali metal negative electrodes were always attractive for metal-oxygen (metal-air) batteries as they show record parameters, which originate from the remarkably negative standard electrode potentials. Such cells have already been designed with lithium [1] or sodium [2] anodes and aprotic electrolytes. Unfortunately the practical specific energies are too far from theoretical values and, at the moment, the application of alkali-metal-air rechargeable batteries is impossible because of the very limited cycle life, which primarily arises from the low chemical stability of the electrolytes [3] and the carbon positive electrodes [4]. The oyxgen reduction reaction, which occurs in the cathodes during the discharge of the batteries, leads to the formation of superoxide anions $\mathrm{O}_{2}{ }^{-}$that can survive in some aprotic solvents for a certain time [5] and participate in various side reactions. In the case of sodium-oxygen cells superoxide quickly associates with $\mathrm{Na}^{+}$ions and forms well-facetted cubic sodium superoxide $\left(\mathrm{NaO}_{2}\right)$ crystals, which are insoluble in the electrolytes and precipitate onto the electrode [2]. The situation is different for lithium-oxygen cells [6-8], in which $\mathrm{LiO}_{2}$ cannot be formed, because it does not exist as a bulk phase at room temperature $[9,10]$. Instead, all the intermediates have to transform into 
lithium peroxide $\left(\mathrm{Li}_{2} \mathrm{O}_{2}\right)$ [11], which always demonstrates a very complex morphology [12] revealing sphere-, torroid- or rozette-like aggregates of plate-like particles. This repeated observation evidences a complex formation mechanism of lithium peroxide.

Here we report a new study of $\mathrm{Li}_{2} \mathrm{O}_{2}$ crystals growth upon the discharge of aprotic lithium-oxygen cells. We show that lithium peroxide plate-like crystals are likely to be formed in the liquid electrolyte phase rather than directly on the electrode surface. $\mathrm{Li}_{2} \mathrm{O}_{2}$ particles aggregate to produce finally submicron crystal clusters with different morphologies. To perform all the experiments, we utilized porous gold electrodes with an enhanced surface area and high stability with respect to all redox processes and interaction with peroxide and superoxide species (see Supporting Information File 1 for details). The porous gold electrodes that were utilized as the model electrodes (Figure 1a) were prepared from gold-silver alloy foils (see Supporting Information File 1 for experimental details). The mean pore size was estimated to be about $200 \mathrm{~nm}$ (see Figure S1 in Supporting Information File 1). This allowed us to observe changes in the morphology of lithium peroxide that are caused by the varying electrochemical experiment conditions. No side processes were expected for the chosen electrodes [13].

The galvanostatic discharge of the cells with such electrodes at different current densities (Figure 1b) in an oxygen-saturated $1 \mathrm{M}$ solution of LiTFSI in dry DMSO resulted in the deposition of a porous $\mathrm{Li}_{2} \mathrm{O}_{2}$ layer on the gold surface (Figure 2a,b). The band at $790 \mathrm{~cm}^{-1}$ in the Raman spectra of the electrodes after the discharge (Figure 2c) is attributed to $\mathrm{O}-\mathrm{O}$ stretch vibrations of lithium peroxide [14]. One of the most important experi- mental conditions is the product generation rate that is being controlled predominantly by the discharge current density. Actually, this parameter determines a supersaturation level, which is required for nucleation and growth of solid phases. We found that the discharge at a lower current density $\left(50 \mu \mathrm{A} / \mathrm{cm}^{2}\right)$ results in more dense $\mathrm{Li}_{2} \mathrm{O}_{2}$ films composed of small building blocks (Figure 2a) while separate stacks of $\mathrm{Li}_{2} \mathrm{O}_{2}$ plate-like crystals grew on the electrode operated at $200 \mu \mathrm{A} / \mathrm{cm}^{2}$ (Figure 2b). The total amount of product formed on the electrodes is higher for low current density, which is in agreement with the area-specific capacities of the cathodes (Figure 1b). Both $\mathrm{Li}_{2} \mathrm{O}_{2}$ film and stacks comprise thin lithium peroxide plates with a diameter varing from 100 to $300 \mathrm{~nm}$ that corresponds to previously published data [15]. A typical TEM image of such platelets is presented in Figure 2d, their size of $30-50 \mathrm{~nm}$ seems to be natural for as-generated nuclei (embryo crystals) rather than for normally grown anisotropic crystals. The plate-like shape of the crystals can be expected as it is predicted by the Wulff rule $[14,15]$.

The observation of the same building blocks that compose the complex morphologies of $\mathrm{Li}_{2} \mathrm{O}_{2}$ obtained in different electrochemical experiments allows to assume that the formation occurs more or less independently from the generation rate of superoxide ions. In the case of a heterogeneous nucleation of platelets on the surface of the gold electrode, a higher discharge current, and thus a higher concentration of the species being crystallized, would result in a denser layer of lithium peroxide, which is, obviously, opposite to our findings (Figure 1a,b). It seems plausible that the lithium peroxide forms aside of the electrode surface which plays the role of a generator for precursors that are subsequently converted to $\mathrm{Li}_{2} \mathrm{O}_{2}$.
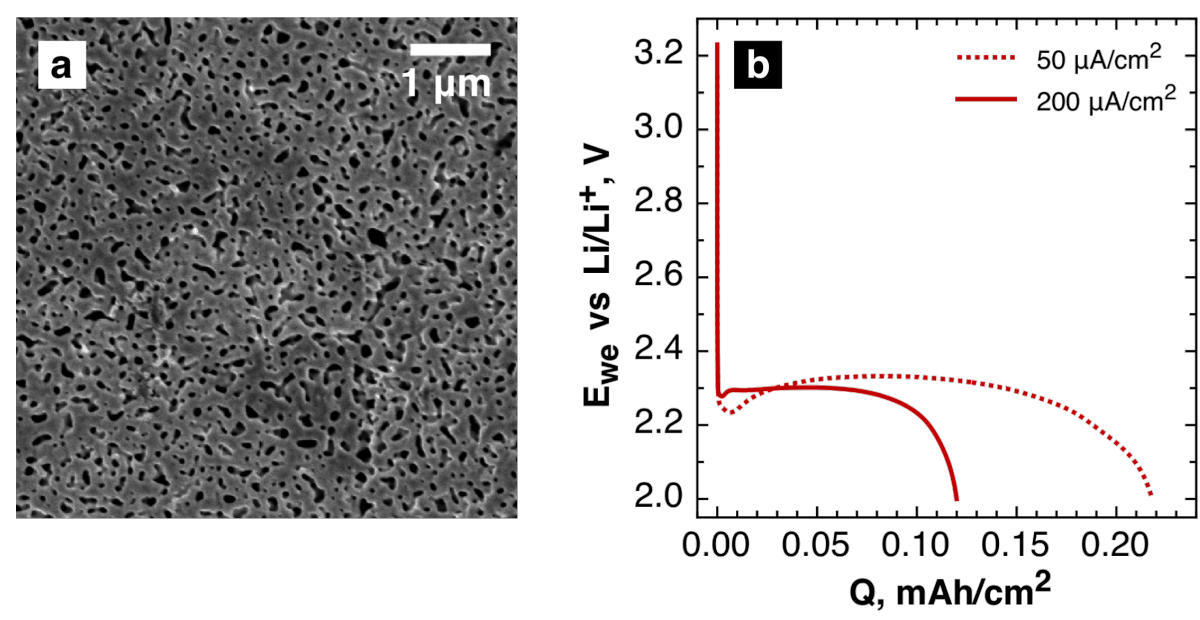

Figure 1: (a) Typical SEM image of the pristine porous gold electrodes. (b) Discharge voltage profiles recorded in a galvanostatic regime at current densities of $50 \mu \mathrm{A} / \mathrm{cm}^{2}$ and $200 \mu \mathrm{A} / \mathrm{cm}^{2}$. 

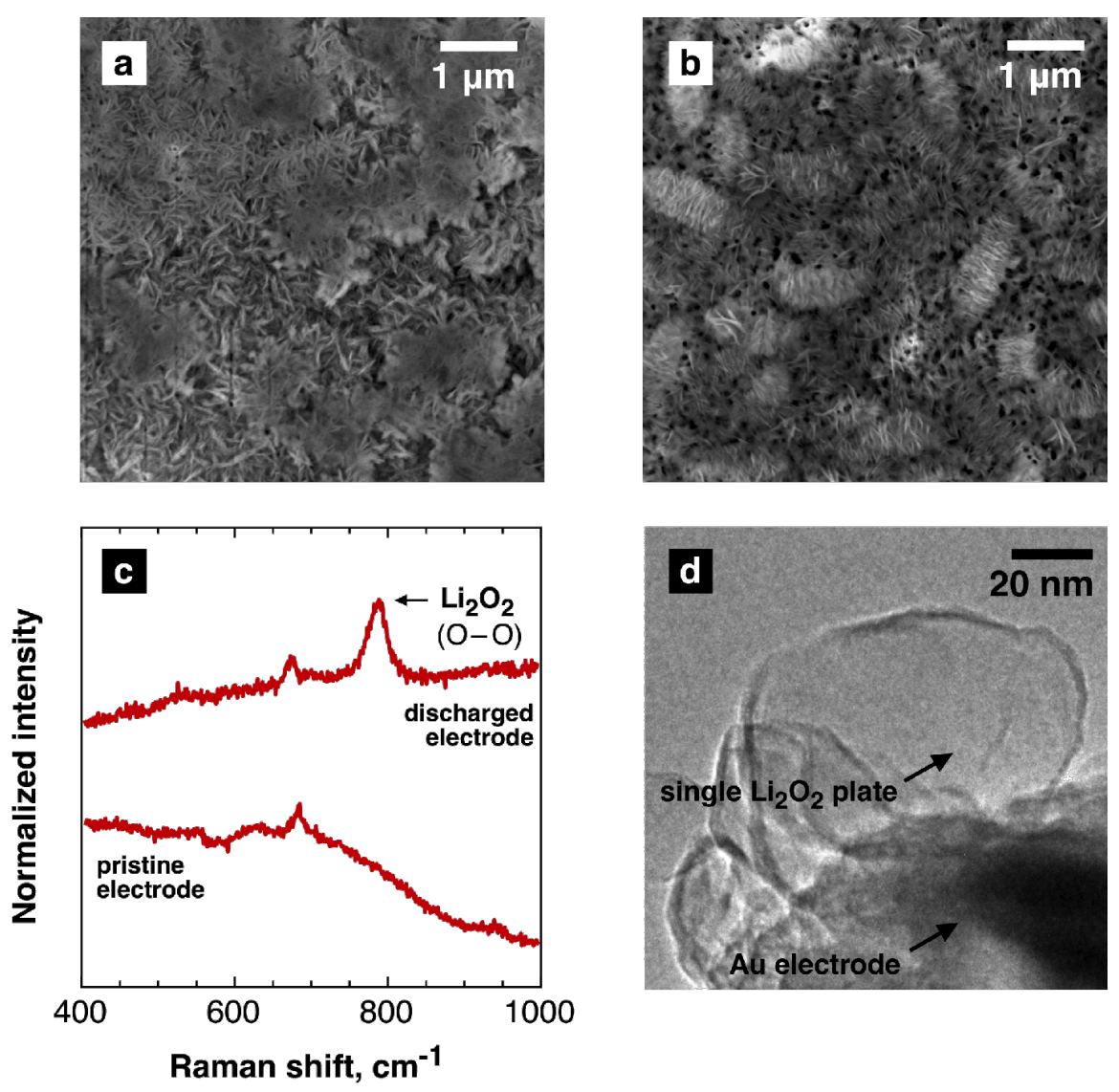

Figure 2: SEM images of the porous gold electrode discharged at $50 \mu \mathrm{A} / \mathrm{cm}^{2}$ (a) and $200 \mu \mathrm{A} / \mathrm{cm}^{2}$ (b). (c) Raman spectra of the pristine and discharged electrodes. (d) TEM image of the porous gold electrode after discharge. $\mathrm{Li}_{2} \mathrm{O}_{2}$ plate edges are deformed by the electron beam.

To find out the most probable way for the generation of such building blocks, we performed a simple experiment purely based on the chemical generation of lithium peroxide in the ion exchange reaction $\mathrm{KO}_{2}+\mathrm{Li}^{+} \rightarrow \mathrm{K}^{+}+1 / 2 \mathrm{Li}_{2} \mathrm{O}_{2}+1 / 2 \mathrm{O}_{2}$.
Figure 3a demonstrates evidently that the morphology of lithium peroxide precipitated after the chemical reaction of $\mathrm{KO}_{2}$ with $\mathrm{Li}^{+}$ions is quite similar to that of lithium peroxide produced in $\mathrm{Li}-\mathrm{O}_{2}$ cells (Figure 2). In the former case the
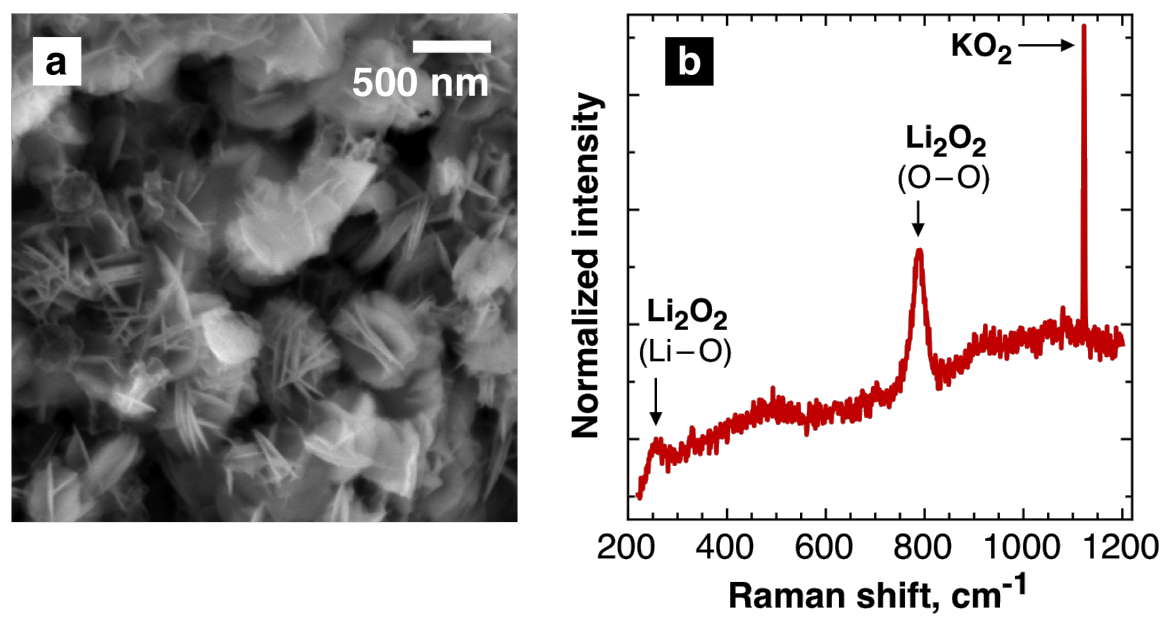

Figure 3: (a) SEM image of the $\mathrm{Li}_{2} \mathrm{O}_{2}$ precipitate obtained by the chemical reaction of $\mathrm{KO}_{2}$ with a solution of LiTFSI. (b) Raman spectra of the precipitate. 
precipitate, which was found to contain $\mathrm{Li}_{2} \mathrm{O}_{2}$ and residual $\mathrm{KO}_{2}$ (Figure 3b), exhibited similar crystal clusters composed of thin platelets. This finding suggests that lithium peroxide particles can be formed right upon the formation of superoxide anions without the influence of the surface of the electrode. After being produced by either the electrochemical ORR or the chemical reaction with $\mathrm{KO}_{2}$, the superoxide anions associate with $\mathrm{Li}^{+}$ which leads to the unstable intermediate that is further converted to $\mathrm{Li}_{2} \mathrm{O}_{2}$. The growth of the lithium peroxide platelike crystals and their further assembly can already occur in the liquid electrolyte.

Scheme 1 illustrates the suggested mechanism of the deposit growth during discharge. At first, molecular oxygen that is dissolved in the electrolyte is reduced to superoxide ions, $\mathrm{O}_{2}+\mathrm{e} \rightarrow \mathrm{O}_{2}^{-}$. These superoxide ions, which carry a negative charge, move away from the electrode surface driven by diffusion [16]. The subsequent disproportionation into a peroxide ion and oxygen, probably by intermolecular collisions as a rate limiting step, $\mathrm{O}_{2}{ }^{-}+\mathrm{O}_{2}{ }^{-} \rightarrow \mathrm{O}_{2}{ }^{2-}+\mathrm{O}_{2}$, results in the generation of lithium peroxide that quickly exceeds a solubility threshold, which was estimated to be about $2.5 \mathrm{mM}$ by (see Figure S3 in Supporting Information File 1). This means that the nucleation proceeds homogeneously and the phase formation is exhausted by the nucleation stage only without an intensive crystal growth because of the relatively high supersaturation that appeared as a result of the fast electrochemical generation of $\mathrm{O}_{2}{ }^{-}$. After that stage, $\mathrm{Li}_{2} \mathrm{O}_{2}$ platelets seem to be formed as observed recently for carbon electrodes [12]. The generated pristine platelets produce a colloidal system under the conditions of their continuous homogeneous nucleation. Most of the layered colloidal systems tend to aggregate if no sufficient electrostatic or steric stabilization is provided. In the particular case of lithium peroxide platelets, they gradually produce submicron crystal clusters with complex morphology.

Thus this study indicates that $\mathrm{Li}_{2} \mathrm{O}_{2}$ crystal clusters are deposited onto the electrode. This layer, however, remains porous, which allows a further mass transport between the electrode and the electrolyte. These deposits can then lose their electric contact with the electrode and thus additionally limit the rechargeablity of the $\mathrm{Li}-\mathrm{O}_{2}$ cell. On the other hand, the special morphology of $\mathrm{Li}_{2} \mathrm{O}_{2}$ provides a larger surface compared to well-facetted crystals or uniform films that might allow a faster recharge. This idea becomes highly interesting in view of recent findings of Chen et al. [17] who suggested a liquid phase mediator. Further work on this topic is in progress.

\section{Supporting Information}

\section{Supporting Information File 1}

Experimental details.

[http://www.beilstein-journals.org/bjnano/content/ supplementary/2190-4286-4-86-S1.pdf]

\section{Acknowledgements}

The authors are grateful to A. Egorov for his kind assistance with the TEM study. Authors appreciate FM Lab LLC. for the support, materials and equipment provided.

\section{References}

1. Abraham, K. M.; Jiang, Z. J. Electrochem. Soc. 1996, 143, 1-5. doi:10.1149/1.1836378

2. Hartmann, P.; Bender, C. L.; Vračar, M.; Dürr, A. K.; Garsuch, A.; Janek, J.; Adelhelm, P. Nat. Mater. 2013, 12, 228-232. doi:10.1038/nmat3486

3. Freunberger, S. A.; Chen, Y.; Peng, Z.; Griffin, J. M.; Hardwick, L. J.; Bardé, F.; Novák, P.; Bruce, P. G. J. Am. Chem. Soc. 2011, 133, 8040-8047. doi:10.1021/ja2021747

4. Itkis, D. M.; Semenenko, D. A.; Kataev, E. Yu.; Belova, A. I.; Neudachina, V. S.; Sirotina, A. P.; Hävecker, M.; Teschner, D.; Knop-Gericke, A.; Dudin, P.; Barinov, A.; Goodilin, E. A.; Shao-Horn, Y.; Yashina, L. V. Nano Lett. 2013, 13, 4697-4701. doi:10.1021/n|4021649

5. Laoire, C. O.; Mukerjee, S.; Abraham, K. M.; Plichta, E. J.; Hendrickson, M. A. J. Phys. Chem. C 2010, 114, 9178-9186. doi:10.1021/jp102019y

6. Lu, Y.-C.; Gallant, B. M.; Kwabi, D. G.; Harding, J. R.; Mitchell, R. R.; Whittingham, M. S.; Shao-Horn, Y. Energy Environ. Sci. 2013, 6, 750-768. doi:10.1039/C3EE23966G

7. Christensen, J.; Albertus, P.; Sánchez-Carrera, R. S.; Lohmann, T.; Kozinsky, B.; Liedtke, R.; Ahmed, J.; Kojic, A. J. Electrochem. Soc. 2012, 159, R1-R30. doi:10.1149/2.086202jes

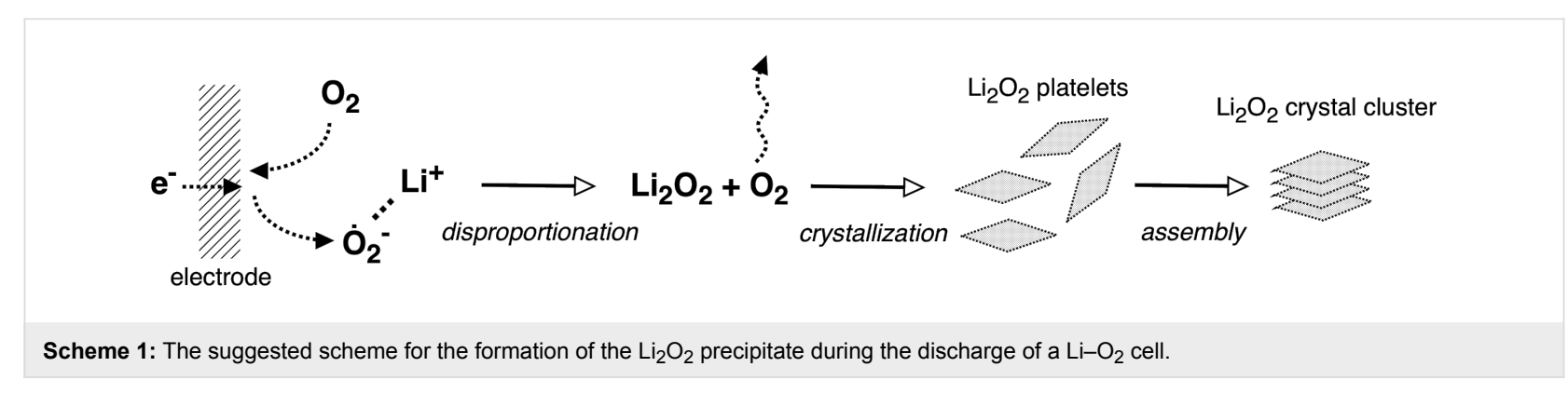


8. Girishkumar, G.; McCloskey, B.; Luntz, A. C.; Swanson, S.; Wilcke, W. J. Phys. Chem. Lett. 2010, 1, 2193-2203. doi:10.1021/jz1005384

9. Lau, K. C.; Curtiss, L. A.; Greeley, J. J. Phys. Chem. C 2011, 115, 23625-23633. doi:10.1021/jp206796h

10. Bryantsev, V. S.; Blanco, M.; Faglioni, F. J. Phys. Chem. A 2010, 114, 8165-8169. doi:10.1021/jp1047584

11. Peng, Z.; Freunberger, S. A.; Hardwick, L. J.; Chen, Y.; Giordani, V.; Bardé, F.; Novak, P.; Graham, D.; Tarascon, J.-M.; Bruce, P. G. Angew. Chem., Int. Ed. 2011, 50, 6351-6355. doi:10.1002/anie.201100879

12. Mitchell, R. R.; Gallant, B. M.; Shao-Horn, Y.; Thompson, C. V. J. Phys. Chem. Lett. 2013, 4, 1060-1064. doi:10.1021/jz4003586

13. Peng, Z.; Freunberger, S. A.; Chen, Y.; Bruce, P. G. Science 2012, 337, 563-566. doi:10.1126/science.1223985

14. Radin, M. D.; Tian, F.; Siegel, D. J. J. Mater. Sci. 2012, 47, 7564-7570. doi:10.1007/s10853-012-6552-6

15. Mo, Y.; Ong, S. P.; Ceder, G. Phys. Rev. B 2011, 84, 205446. doi:10.1103/PhysRevB.84.205446

16. Herranz, J.; Garsuch, A.; Gasteiger, H. A. J. Phys. Chem. C 2012, 116, 19084-19094. doi:10.1021/jp304277z

17. Chen, Y.; Freunberger, S. A.; Peng, Z.; Fontaine, O.; Bruce, P. G. Nat. Chem. 2013, 5, 489-494. doi:10.1038/NCHEM.1646

\section{License and Terms}

This is an Open Access article under the terms of the Creative Commons Attribution License (http://creativecommons.org/licenses/by/2.0), which permits unrestricted use, distribution, and reproduction in any medium, provided the original work is properly cited.

The license is subject to the Beilstein Journal of

Nanotechnology terms and conditions:

(http://www.beilstein-journals.org/bjnano)

The definitive version of this article is the electronic one which can be found at:

$\underline{\text { doi:10.3762/bjnano. } 4.86}$ 